\title{
Establishment of a Rapid Plant Regeneration System in Physalis angulata L. through Axillary Meristems
}

\author{
Owk ANIEL KUMAR, Songa RAMESH, Sape SUBBA TATA*
}

AndhraUniversity,_DepartmentofBotany,Visakhapatnam,India; owkanielkumar@yahoo.com;songaramesh1@gmail.com;s_tata_s@yahoo.co.in(correspondingauthor)

\begin{abstract}
An optimal plant propagation method of Physalis angulata L., a medicinally important herbaceous plant species has been developed using axillary meristem explants. Shoot bud proliferation was initiated from axillary meristem explants cultured on MS medium supplemented with various concentrations of $0.5-2.5 \mathrm{mg} / \mathrm{L} /(\mathrm{BAP}) /($ Zeatin $) /(\mathrm{KIN})$. The maximum in vitro response of shooting frequency of explants (88.1\%) and shoots per explant (42) was achieved with medium containing 1.0mg/L BAP. Multiple shoot culture was established by repeated subculturing of the shoot buds of axillary meristems on shoot multiplication medium. Among the subculture media BAP in combination with $1.5 \mathrm{mg} / \mathrm{L}(\mathrm{IAA})+0.25 \mathrm{mg} / \mathrm{L}(\mathrm{GA} 3)$ produced maximum shoots per explant $(128 \pm 0.29)$ after two weeks of culture. Effective in vitro shoot elongation and rooting was achieved on $1.0 \mathrm{mg} / \mathrm{L}\left(\mathrm{GA}_{3}\right)$ and $1.0 \mathrm{mg} / \mathrm{L}(\mathrm{IBA})$, respectively. Most of the generated shoots were successfully transferred to soil under field conditions. The survival percentage of the transferred plants on soil was found to be 90 per cent. This protocol can be used for commercial propagation and for future genetic improvement studies.
\end{abstract}

Keywords: axillary meristem, conservation, multiple shoots, Physalis angulata, rhizogenesis, zeatin

Abbreviations: BAP (Benzyl amino purine), IAA (Indole acetic acid), IBA (Indole butyric acid), KIN (Kinetin), PGR (Plant growth regulator)

\section{Introduction}

Medicinal plants play a crucial role in health care needs of people around the world especially in developing countries (Rao et al., 2004; Bekalo et al., 2009). About $80 \%$ of the population from developing countries still depends on the use of traditional medicine (Cunningham, 1993). Physalis angulata L. belongs to Solanaceae family and it is distributed throughout tropical countries (Sultana, 2008). The plant have multimedicinal applications against various diseases such as bladder, spleen and liver inflammations (Pinto et al., 2010), sedative (Agra et al., 2007), depurative, antirheumatic, relief of earache, diabetes and hepatitis (Lawal et al., 2010), asthma (Rathore et al., 2011), malaria (Ruiz et al., 2011), cancer (Hseu et al., 2011), antipyretic and antinociceptive (Bastos et al., 2006), antidiuretic (Nanumala, 2012), sore throat, abdominal pain and cervicitis (Mahalakshmi et al., 2014). Besides this, plant also shows good antibacterial and antifungal activities (Osho et al., 2010). Conventionally this plant is propagated through seeds. Natural population of this plant species is decreasing due to indiscriminate exploitation and this has been the trend for decades in developing countries (Navdeep et al., 2015). Therefore, it is necessary that a systematic propagation to be introduced in order to conserve biodiversity and protect these highly medicinal plant species. The plant regeneration from meristems is considered to be one of the most promising ways for multiplying a selected variety true to its type. Such individuals are genetically similar showing the same agronomic characteristics. To our knowledge there are no published reports on multiplication of Physalis angulata L. However, plant regeneration studies have been reported in different species of Physalis viz., P. perwviana (Otroshy et al., 2013), P. minima (Farhana et al., 2009; Arvind et al., 2011), P. pubescence (Rao et al., 2004; Mona. 2013), P. ixocarpa (Guzman et al., 2009). Hence the in vitro propagation of this medicinally important species was undertaken. The present study describes the maximization of shoot multiplication through in vitro regeneration of Physalis angulata L. by axillary meristem explants using standard culture medium fortified with different plant growth regulators. The protocols presented here should become a valuable part of future efforts in genetic improvement of Physalis angulata.

\section{Materials and Methods}

\section{Plant material and explant source}

One month old plants of Physalis angulata L. grown in the Experimental Farm of Botany, Andhra University were selected as stock plants. The leaves and roots were discarded and shoots were washed thoroughly under running tap water for $20 \mathrm{~min}$. Axillary portion was used as an explant.

\section{Surface sterilization}

Axillary meristem explants were washed thoroughly in running tap water for $10 \mathrm{~min}$, then treated with two drops of 
472

aqueous surfactant Tween 20 (5\% v/v) for $5 \mathrm{~min}$, followed by repeated rinsing with distilled water. Further, sterilization was done under aseptic conditions in Laminar Air Flow cabinet. Explants were surface sterilized with $50 \%(\mathrm{v} / \mathrm{v})$ ethyl alcohol (1min) followed by $0.1 \%(\mathrm{w} / \mathrm{v}) \mathrm{HgCl}_{2}$ (3min). Finally, the explants were washed thoroughly (3 to 5 times) with sterilized distilled water to remove traces of $\mathrm{HgCl}_{2}$.

\section{Culturemedium}

Axillary meristem stem explants appropriate size (about $1 \mathrm{~cm}$ ) were cultured on sterilized MS media (MS basal and MS with different concentrations of auxins [IAA(indole acetic acid), IBA(indole butyric acid)], cytokinins [BAP(benzyl amino purine), Zeatin, $\mathrm{KIN}\left(\right.$ kinetin)] and $\mathrm{GA}_{3}$ (gibberellic acid) alone and in combined forms. All the media consists with $3 \%(\mathrm{w} / \mathrm{v})$ sucrose and gelled with $0.8 \%$ (w/v) agar-agar (Murashige and Skoog, 1962). The $\mathrm{pH}$ of all media was adjusted to 5.8 and sterilized by autoclave at $121^{\circ} \mathrm{C}$ for $15 \mathrm{~min}$. The cultures were incubated at $22 \pm 2^{\circ} \mathrm{C}$ under a $16 \mathrm{~h}$ photoperiod $\left(50 \mu \mathrm{E}^{-2} \mathrm{~s}^{-1}\right.$ irradiance $)$ provided by cool white fluorescent tubes.

\section{Directmultiple shoot induction and multiplication}

For direct shoot bud induction, the axillary meristem explants were cultured on $\mathrm{MS}+0.5-2.5 \mathrm{mg} / \mathrm{L}(\mathrm{BAP}) /($ Zeatin $) /(\mathrm{KIN})$ individually. After four weeks of incubation, the developed multiple shoots were subcultured on..MS+0.5$2.5 \mathrm{mg} / \mathrm{L}(\mathrm{BAP}) /($ Zeatin $) /(\mathrm{KIN})+0.5 \mathrm{mg} / \mathrm{L}(\mathrm{IAA})+0.25 \mathrm{gm} / \mathrm{L}\left(\mathrm{GA}_{3}\right)$ for further shoot proliferation.

\section{Shoot elongation and rhizogenesis}

For shoot elongation, the microshoots from the multiple shoot clusters were cultured on MS medium fortified with different concentrations of $\mathrm{GA}_{3}(0.5-2.0 \mathrm{mg} / \mathrm{L})$. Following shoot elongation, the elongated shoots were transferred onto MS medium supplemented with various concentration of IBA (0.5$2.0 \mathrm{mg} / \mathrm{L}$ ) individually for Rhizogenesis. Observations were taken at the end of the second week respectively.

\section{Acclimatization}

Well rooted plantlets were thoroughly washed to remove the adhering gel and planted in $10 \mathrm{~cm}$ plastic cups containing a mixture of peat moss and organic manure (1:1). Plastic cups were covered with polythene bags to maintain humidity. Plants were kept in culture room for ten days. Half strength MS macro salts was poured to the plastic cups at five day regular intervals until the new leaves developed. Plants were transferred to pots containing organic manure, garden soil and forest humus (1:1:1). The pots were watered at a two day interval and were maintained in greenhouse. The survival rate was recorded one month after transfer to pots.

\section{Data analysis}

Experiments were set up in Randomized Block Design (RBD) and each experiment was repeated thrice with fifteen replicates. The results observed at regular intervals and tabulated. Mean and Standard Error values were carried out for each treatment.

\section{Results and Discussion}

Axillary meristem explants were excised from natural plants and were cultured on different plant growth regulator (PGR) regimes. The MS medium without any PGR was failed to induce in vitro response (Table 1). Direct regeneration was found in all concentrations of cytokinins alone with MS medium at four weeks of culture. This indicates the necessity for supplementation of plant growth regulators externally for induction of multiple shoots (Sasikumar et al., 2009). Of the three cytokinins tested, BAP treated explants achieved higher regeneration than those treated with Zeatin and $\mathrm{KIN}$ (Table 1). The $1.0 \mathrm{mg} / \mathrm{L}(\mathrm{BAP})$ treatment yielded maximum regeneration $(88.1 \%)$ and number of shoots per explant $(42.0 \pm 0.19)$ (Table 1 and Fig. 1a). The ability of BAP to induce in vitro response is well documented (George, 1993). In general, herbaceous plants are highly responsive to BAP treatment and most cultured herbaceous species produces robust, well-formed shoots suitable for further shoot proliferation (Debergh and Zimmerman, 1999). At BAP, Zeatin and KIN concentrations being higher than $1.0 \mathrm{mg} / \mathrm{l}$, the number of shoots as well as the percentage response was lower. Similar study was also reported in species P. minima (Farhana et al., 2009). Further the shoot buds were repeatedly subculturing on MS media fortified with 0.5 $2.5 \mathrm{mg} / \mathrm{L} /(\mathrm{BAP}) /($ Zeatin $) /(\mathrm{KIN})+0.5 \mathrm{mg} / \mathrm{L}(\mathrm{IAA})+0.25 \mathrm{mg} /$ $\mathrm{L}\left(\mathrm{GA}_{3}\right)$ for inducing adventitious multiple shoots. Enhanced

Table 1. Effect of cytokinins on axillary meristems of Physalis angulata $\mathrm{L}$. at four weeks of culture

\begin{tabular}{|c|c|c|c|c|c|}
\hline \multirow{2}{*}{ S.No. } & \multicolumn{3}{|c|}{ MS medium fortified with cytokinins $(\mathrm{mg} / \mathrm{L})$} & \multicolumn{2}{|c|}{ In vitro response } \\
\hline & BAP & Zeatin & KIN & Shooting (\%) & Shoot no./ explants \\
\hline 01. & - & - & - & $00.0 \pm 0.00$ & $00.0 \pm 0.00$ \\
\hline 02. & 0.5 & - & - & $73.7 \pm 0.38$ & $26.0 \pm 0.20$ \\
\hline 03. & 1.0 & - & - & $88.1 \pm 0.33$ & $42.0 \pm 0.19$ \\
\hline 04. & 1.5 & - & - & $77.4 \pm 0.59$ & $32.0 \pm 0.25$ \\
\hline 05. & 2.0 & - & - & $69.4 \pm 0.68$ & $26.0 \pm 0.36$ \\
\hline 06. & 2.5 & - & - & $64.4 \pm 0.68$ & $18.0 \pm 0.31$ \\
\hline 07. & - & 0.5 & - & $68.6 \pm 0.49$ & $16.0 \pm 0.30$ \\
\hline 08. & - & 1.0 & - & $71.1 \pm 0.23$ & $24.0 \pm 0.16$ \\
\hline 09. & - & 1.5 & - & $69.7 \pm 0.50$ & $20.0 \pm 0.10$ \\
\hline 10. & - & 2.0 & - & $66.7 \pm 0.19$ & $17.0 \pm 0.23$ \\
\hline 11. & - & 2.5 & - & $58.7 \pm 0.38$ & $12.0 \pm 0.28$ \\
\hline 12. & - & - & 0.5 & $54.0 \pm 0.33$ & $10.0 \pm 0.14$ \\
\hline 13. & - & - & 1.0 & $63.1 \pm 0.33$ & $16.0 \pm 0.29$ \\
\hline 14. & - & - & 1.5 & $60.0 \pm 0.33$ & $12.0 \pm 0.38$ \\
\hline 15. & - & - & 2.0 & $52.1 \pm 0.33$ & $08.0 \pm 0.20$ \\
\hline 16. & - & - & 2.5 & $52.0 \pm 0.33$ & $05.0 \pm 0.21$ \\
\hline
\end{tabular}

Values are mean \pm SE of Fifteen replicates 
Table 2. Effect of PGR's on proliferation of shoot buds of Physalis angulata L. at two weeks of culture

\begin{tabular}{|c|c|c|c|c|c|c|}
\hline \multirow{2}{*}{ S.No. } & \multicolumn{5}{|c|}{ MS medium fortified with plant growth regulators $(\mathrm{mg} / \mathrm{L})$} & \multirow{2}{*}{ No. of multiple shoots/explant } \\
\hline & BAP & Zeatin & KIN & IAA & $\mathrm{GA}_{3}$ & \\
\hline 01. & 0.5 & - & - & 0.5 & 0.25 & $74.00 \pm 0.40$ \\
\hline 02. & 1.0 & - & - & 0.5 & 0.25 & $128.00 \pm 0.29$ \\
\hline 03. & 1.5 & - & - & 0.5 & 0.25 & $98.50 \pm 0.32$ \\
\hline 04. & 2.0 & - & - & 0.5 & 0.25 & $90.00 \pm 0.24$ \\
\hline 05. & 2.5 & - & - & 0.5 & 0.25 & $82.80 \pm 0.19$ \\
\hline 06. & - & 0.5 & - & 0.5 & 0.25 & $24.00 \pm 0.15$ \\
\hline 07. & - & 1.0 & - & 0.5 & 0.25 & $74.00 \pm 0.18$ \\
\hline 08. & - & 1.5 & - & 0.5 & 0.25 & $60.00 \pm 0.27$ \\
\hline 09. & - & 2.0 & - & 0.5 & 0.25 & $55.80 \pm 0.20$ \\
\hline 10. & - & 2.5 & - & 0.5 & 0.25 & $46.70 \pm 0.30$ \\
\hline 11. & - & - & 0.5 & 0.5 & 0.25 & $15.00 \pm 0.22$ \\
\hline 12. & - & - & 1.0 & 0.5 & 0.25 & $60.00 \pm 0.32$ \\
\hline 13. & - & - & 1.5 & 0.5 & 0.25 & $49.50 \pm 0.23$ \\
\hline 14. & - & - & 2.0 & 0.5 & 0.25 & $45.00 \pm 0.10$ \\
\hline 15. & - & - & 2.5 & 0.5 & 0.25 & $22.70 \pm 0.14$ \\
\hline
\end{tabular}

Values are mean \pm SE of Fifteen replicates

Table 3. Effect of $\mathrm{GA}_{3}$ on elongation of micro shoots of Physalis angulata $\mathrm{L}$. at two weeks of culture

\begin{tabular}{ccc}
\hline S.No. & $\begin{array}{c}\text { MS medium fortified with } \\
\mathrm{GA}_{3}(\mathrm{mg} / \mathrm{L})\end{array}$ & Shoot length $(\mathrm{cm})$ \\
\hline 1. & 0.00 & $00.00 \pm 0.00$ \\
2. & 0.50 & $09.00 \pm 0.06$ \\
3. & 1.00 & $12.00 \pm 0.10$ \\
5. & 1.50 & $11.00 \pm 0.22$ \\
6. & 2.00 & $10.00 \pm 0.14$ \\
\hline
\end{tabular}

Values are mean \pm SE of Fifteen replicates
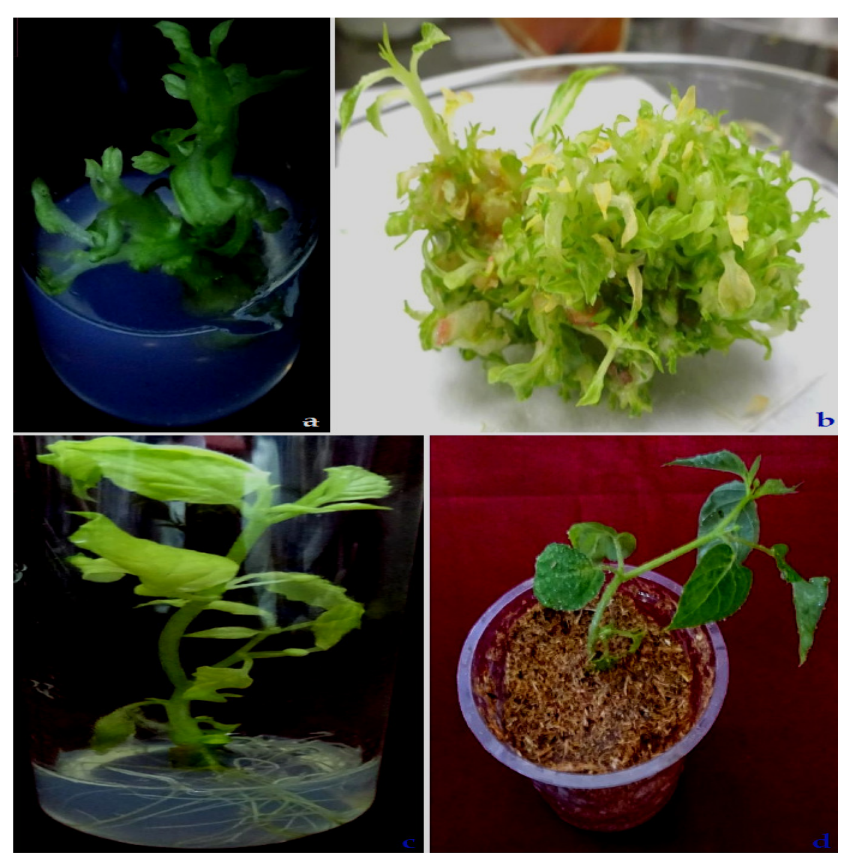

Fig. 1. In vitro plant regeneration of Physalis angulata $\mathrm{L}$.

(a) Direct shoot bud induction from axillary meristem, (b) Proliferating multiple shoots, (c) Rooted plantlet, (d) In vitro developed plant after acclimatization

shoot multiplication in subsequent subculture is in accordance with published literature on medicinal plants like Solanum nigrum (Kavitha et al., 2012), Catharanthus roseus (Pandey et al., 2014) and Orthosiphon stamineus (Sheena et al., 2015). An average of 128 shoots was obtained from a single axillary meristem after two weeks of culture (Table 2 and Fig. 1b). According to the previous research outcomes on plant regeneration from different Physalis species viz., $P$. pubescens L. (Rao et al., 2004; Mona, 2013), P. ixocarpa Brot. (Guzman
Table 4. Rhizogenesis of elongated shoots of Physalis angulata L at two weeks of culture

\begin{tabular}{ccccc}
\hline S.No. & $\begin{array}{c}\text { MS medium } \\
\text { fortified with } \\
\text { IBA }(\mathrm{mg} / \mathrm{L})\end{array}$ & $\begin{array}{c}\text { Root induction } \\
(\%)\end{array}$ & $\begin{array}{c}\text { Root No./ } \\
\text { shoot }\end{array}$ & $\begin{array}{c}\text { Root length } \\
(\mathrm{cm})\end{array}$ \\
\hline 01. & 0.00 & $00.0 \pm 0.00$ & $00.0 \pm 0.00$ & $00.0 \pm 0.00$ \\
02. & 0.50 & $72.0 \pm 0.18$ & $15.0 \pm 0.18$ & $10.2 \pm 0.23$ \\
\hline 03. & 1.00 & $100 \pm 0.00$ & $18.2 \pm 0.10$ & $14.5 \pm 0.20$ \\
04. & 1.50 & $85.0 \pm 0.29$ & $13.6 \pm 0.22$ & $9.0 \pm 0.11$ \\
\hline 05. & 2.00 & $66.0 \pm 0.22$ & $9.4 \pm 0.06$ & $5.8 \pm 0.14$ \\
\hline Values are mean \pm SE of Fifteen replicates & & \\
\hline
\end{tabular}

et al., 2009) and P. minima L. (Arvind et al., 2011; Ramar, 2014) the present investigation proved the best regeneration capacity. The shoots lengthen from $1.0 \mathrm{~cm}$ to $1.5 \mathrm{~cm}$ were separated from multiple shoot cluster and transferred to MS medium containing $\mathrm{GA}_{3}(0.5-2.0 \mathrm{mg} / \mathrm{L})$ for shoot elongation. The maximum shoot elongation $(8 \mathrm{~cm} / \mathrm{shoot})$ was achieved on MS medium fortified with $\mathrm{GA}_{3}(1.0 \mathrm{mg} / \mathrm{L})$ (Table 3). The elongated shoots were separated and transferred to MS medium containing different concentrations of IBA for root induction. Emergence of roots occurred within a period of one week. Further incubation of one week led to a very vigorous root growth. The maximum root growth was recorded on MS with $1.0 \mathrm{mg} / \mathrm{L}$ of IBA as a supplement (Table 4 and Fig. 1c). Similar effects of IBA were also observed in Solanum trilobatum (Arockiasamy et al., 2002) and Physalis peruviana (Otroshy et al., 2013). After sequential hardening, the plantlets were transferred to greenhouse where $90 \%$ of them survived (Fig. 1d).

\section{Conclusions}

The present study presents a rapid, efficient and reliable micropropagation protocol for in vitro regeneration of Physalis angulata L. from axillary meristem explants. The described protocol can be used for large scale propagation and may become a valuable part of strategies for ex situ conservation of this important medicinal herb.

\section{Acknowledgements}

The authors Ramesh is grateful to UGC-SAP-CAS-I, Department of Botany, Andhra University and UGC-RGNF for providing financial assistance. 


\section{References}

Agra M, Baracho G, Nurit K, Basílio I, Coelho V (2007). Medicinal and poisonous diversity of the flora of "Cariri Paraibano", Brazil. J Ethnopharmacol 111:383-395.

Arockiasamy DI, Muthukumar B, Natarajan E, Britto SJ (2002). Plant regeneration from node and internode explants of Solanum trilobatum L. Plant Tissue Culture 12(2):93-97.

Arvind JM, Vilas DD, Rahul BK, Alka C, Prakash Z (2011). In vitro callus induction and shoot regeneration in Physalis minima $\mathrm{L}$. Annals of Biological Research 2(2):79-85.

Bastos GN, Santos A, Ferreira V, Costa A, Bispo C, Silveira A, Do Nascimento J (2006). Antinociceptive effect of the aqueous extract obtaines from roots of Physalis angulata L. on mice. Journal of Ethnopharmacology 103:241-245.

Bekalo TH, Woodmatas SD, Woldemarian ZA (2009). An ethnobotanical study of medicinal plants used by local people in the lowlands of Konta special Woreda, Southern nations, nationalities and peoples regional state Ethiopia. Journal of Ethnobiology and Ethnomedicine 5:26.

Cunningham AB (1993). African medicinal plants. Setting priorities at the interface between conservation and primary healthcare. People and plants working paper 1,92. UNESCO, Paris.

Debergh PC, Zimmerman RH (1999). Micropropagation technology and application. Kluwer Academic Publishers, Dordrecht, Netherlands.

Farhana A, Sayeed Hassan AKM, Laila Shamroze B, Rebeka S, Nadira B, Miskat AAJ, Rahima K (2009). In vitro shoot proliferation and plant regeneration of Physalis minima L. - a perennial medicinal herb. Bangladesh Journal of Scientific and Industrial Research 44(4):453-456.

George EF (1993). Plant propagation by tissue culture. Part 1. The Technology, Exegetics Ltd, Edington, Wilts, UK.

Guzman REE, Godinez FH, De La Vega OM, Alejo NO (2009). In vitro embryo formation and plant regeneration from anther culture of different cultivars of Mexican husk tomato (Physalis ixocarpa Brot.) Plant Cell Tissue and Organ Culture 96:181-189.

Hseu Y, Wu C, Chang H, Kumar K, Lin M, Chen C, Cho H, Huang C, Huang C, Lee H, Hsieh W, Chung J, Wang H, Yang H (2011). Inhibitory effects of Physalis angulata on tumor metastasis and angiogenesis. Journal of Ethnopharmacology 135:762-771.

Kavitha MS, Wesely EG, Mehalingam P (2012). Direct multiple shoot regeneration from shoot tip and nodal explants of Solanum Nigrum L. a medicinal herb. Journal of Ornamental and Horticultural Plants 2(2):65-72.

Lawal I, Uzokwe N, Igboanugo A, Adio A, Awosan E, Nwogwugwu J, Faloye B, Olatunji B, Adesoga A (2010). Ethno medicinal information on collation and identification of some medicinal plants in Research Institutes of South-west Nigeria. African Journal of Pharmacy and Pharmacology 4:1-7

Mahalakshmi AM, Ramesh BN (2014). Physalis angulata L.: An ethanopharmacological review. Indo American Journal of Pharmaceutical Research 4(3): 1479-1486.
Mona MY (2013). In vitro propagation and somatic embryogenesis in Egyptian husk tomato (Physalis pubescens L.). Journal of Applied Sciences Research 9(3):1415-1425.

Murashige T, Skoog F (1962) A revised medium for rapid growth and bioassays with tobacco tissue cultures. Physiology Plantarum 15:473497.

Nanumala SK, Gunda K, Runja C, Sriram Chandra M (2012). Evaluations of diuretic activity of methanolic extract of Physalis angulata L. leaves. International Journal of Pharmaceutical Sciences Review and Research 16:40-42.

Navdeep S, Anisha B, Harcharan SD, Vivek S (2015). Perspectives and possibilities of Indian species of genus Physalis (L.) - a comprehensive review. European Journal of Pharmaceutical and Medical Research 2(2):326-353.

Osho A, Adetunji T, Fayemi S, Moronkola D (2010). Antimicrobial activity of essential oils of Physalis angulata L. African Journal of Traditional, Complementary, and Alternative Medicines 7:303-306.

Otroshy M, Arash M, Sayyed MMK, Amir-Hossein B (2013). Direct regeneration from leaves and nodes explants of Physalis perwiana $\mathrm{L}$. International Journal of Farming and Allied Sciences 2(9):214-218.

Pandey S, Bahadur AN, Kanungo VK, Tiwari U (2014). In vitro propagation of a medicinal plant Catharanthus roseus L. (G.) Don. Indian Journal of Scientific Research 4(1):125-128.

Pinto N, Morais T, Carvalho K, Silva C, Andrade G, Brito G, Veras M, Pessoa O, Rao V, Santos F (2010). Topical anti-inflammatory potential of physalin E from Physalis angulata on experimental dermatitis in mice. Phytomedicine 17:740-743.

Ramar K, Ayyadurai V (2014). In vitro direct multiple shoot induction and flower initiation of Physalis minima $(\mathrm{L})$. An important medicinal plant. Journal of International Academic Research for Multidisciplinary 3(1):119-124.

Rao YV, Ravi A, Lakshmi TVR, Raja KG (2004). Plant regeneration in Physalis pubescens L. and its induced mutant. Plant Tissue Culture 14(1):9-15.

Rao MR, Palada MC, Becker BN (2004). Medicinal and aromatic plants in agroforestry systems. Agroforestry Systems 61:107-122.

Rathore C, Dutt K, Sahu S, Deb L (2011). Antiasthmatic activity of the methanolic extract of Physalis angulata Linn. Journal of Medicinal Plants Research 5:5351-5355.

Ruiz L, Ruiz L, Maco M, Cobos M, Gutierrez-Choquevilca A, Roumy V (2011). Plants used by native Amazonian groups from the Nanay River (Peru) for the treatment of malaria. Journal of Ethnopharmacology 133:917-921.

Sasikumar S, Ranveendar S, Premkumar A, Ignacimuthu S, Agastian P (2009). Micropropagation of Baliospermum montanum (Willd.) Muell. Arg. - A threatened medicinal plant. Indian Journal of Biotechnology 8:223-226.

Sheena EV, Jeya Jothi G (2015). In vitro propagation of Orthosiphon stamineus Benth (Lamiaceae) an important medicinal plant using nodal and leaf explants. The Pharma Innovation Journal 4(7):6-10.

Sultana N, Hassan MA, Begum H, Sultana M (2008). Physalis angulata L. (Solanaceae) - A new angiospermic record for Bangladesh. Bangladesh Journal of Botany 37(2):195-198. 